Journal of Science
http://dergipark.gov.tr/gujs

\title{
Phenolic Content, Antioxidant and Antimicrobial Potential of Endemic Ferulago platycarpa
}

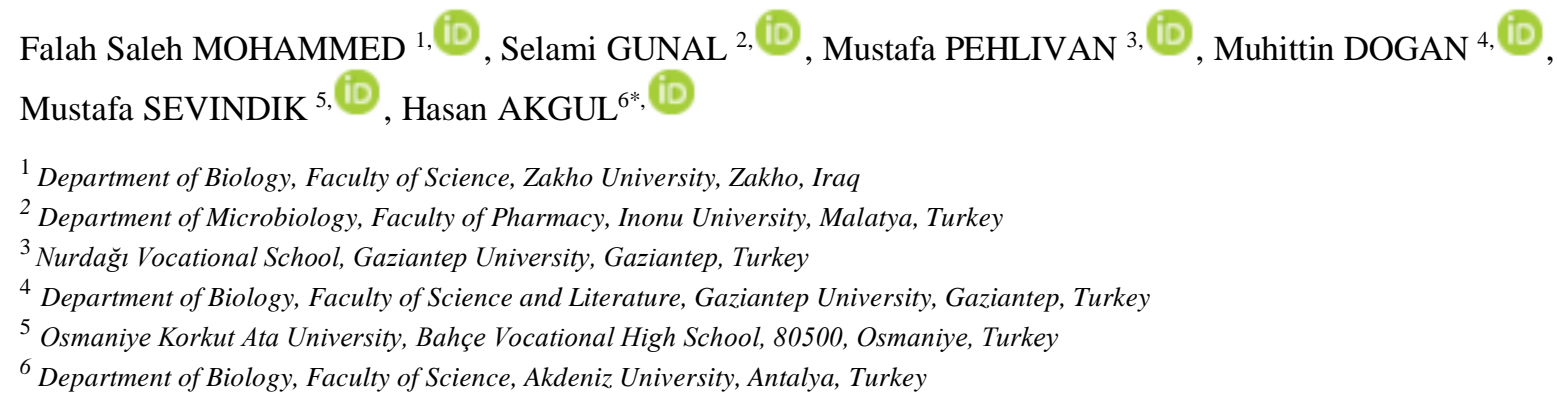

\section{Highlights}

- In this study, biological activities of endemic Ferulago platycarpa were determined.

- In this study, TAS, TOS and OSI values of Ferulago platycarpa were determined for the first time.

- In this study, Phenolic contents of Ferulago platycarpa were determined.

\section{Article Info \\ Received: $22 / 03 / 2020$ Accepted: 31/05/2020 \\ Keywords \\ Ferulago platycarpa Endemic \\ Antioxidant \\ Antimicrobial \\ Phenolic content}

\begin{abstract}
In this study, biological activities and phenolic contents of endemic Ferulago platycarpa Boiss. $\&$ Bal. were determined. Within the scope of biological activity, antimicrobial activity, antioxidant and oxidant status of plant extracts were determined. Phenolic contents were determined by using HPLC. Antimicrobial activity was determined against bacteria and fungus strains using the modified agar method. Antioxidant and oxidant status were calculated with Rel Assay kits. Gallic, chlorogenic, cinnamic, syringic acids, epicatechin, catechin and quercetin were found in the plant. It was also determined that the plant has antioxidant and antimicrobial potential. But, because of higher TOS value, it was considered that the plants, which were collected from region suitable for OSI value, could be a natural antioxidant source.
\end{abstract}

\section{INTRODUCTION}

Throughout human history, plants have always been a natural resource for humans [1]. Plants were used initially by instinct or by imitating animals. Over time, it became a more rational use as a result of discoveries made through trial and error [2,3]. All these discoveries made through trial and error, combined with beliefs and practices, have been transferred from generation to generation throughout the ages and have formed great information $[4,5]$. Today, the fact that $75 \%$ of the natural herbal compounds used in the treatment have been discovered as a result of researches on traditional folk medicine reveals how valuable this information [6].

In recent years, the use of many natural herbs has increased due to the decreased reliability of synthetic drugs. In addition, the food and cosmetics industry has also turned to natural products. Therefore, studies on secondary metabolites synthesized by plants are increasing. [7].

Apiaceae, a very cosmopolitan family throughout the world, is one of the families known to contain essential oils. It is known that most of the family-related species are concentrated in Asia [8,9]. Ferulago 
genus, belonging to the family Apiaceae, contains many bioactive components. It is represented in the world by about 50 taxa. The countries in which the Ferulago species has the greatest biodiversity are Asian countries such as China, Turkey, Iran, Russia and Kazakhstan. In Turkey, Ferulago species are commonly known as 'Çakşır' or 'Çağşır', represented by 35 taxa and 18 of them are endemics. This situation shows that Turkey may be the gene center of Ferulago $[8,10]$.

Ferulago species are consumed as food in the form of pickles in Turkey. They are also known as odorant and preservative in dairy products, especially in cheese [11]. The genus is used in the treatment of hemorrhoids, intestinal worms, ulcers, snake bites, digestive problems and headaches. It is also known that the genus has sedative and stimulant effects $[8,12]$. Because of these wide uses, studies on the biological activities of the genus have accelerated in recent years and the results obtained from these studies have revealed that Ferulago has anti-cancer, immunomodulatory, anti-proliferative, anti-apoptotic, antibacterial, anti-fungal, anti-viral, anti-oxidant and anti-coagulant effects $[7,8,10]$.

In this study, endemic Ferulago platycarpa Boiss. \& Bal. was used as material. The antioxidant, oxidant and antimicrobial activities of the plant extracts were determined. In addition, phenolic compounds were screened.

\section{MATERIAL AND METHOD}

Plant samples were collected from Gaziantep province. Herbarium specimens of the plants collected from field studies were kept in the herbarium at Department of Biology, Gaziantep University. Plant samples were dried under suitable conditions. After drying, methanol, ethanol and dichloromethane extracts of plant samples were extracted in a Soxhlet (Gerhardt EV 14) extractor. The extracts were then concentrated on Heidolph Laborator 4000 Rotary Evaporator and then, they were stored at $+4{ }^{\circ} \mathrm{C}$ before experiments.

\subsection{Determination of Phenolic Contents}

Phenolic compounds in the plant were screened using HPLC (SHIMADZU) device [13]. The injection volume was adjusted to be $20 \mu \mathrm{L}$. Mobile phase: A: $3 \%$ acetic acid, B: methanol. The flow rate was regulated to be $0.8 \mathrm{~mL}$ per minute. Chromatographic separation was carried out with an Agilent Eclipse XDB-C18 column (250x4.6 mm; id $5 \mu \mathrm{m})$ at $30^{\circ} \mathrm{C}$.

\subsection{TAS, TOS and OSI}

The antioxidant (TAS/mmol Trolox equiv./L) and oxidant status (TOS/ $\mu$ mol $\mathrm{H}_{2} \mathrm{O}_{2}$ equiv./L) of plant extracts were calculated with Rel Assay kits. Trolox and hydrogen peroxide were used as the calibrator. OSI value (arbitrary unit: AU) was determined by the ratio of TOS values to TAS values $[14,15]$.

\subsection{Antimicrobial activity}

Antimicrobial activities of plant extracts were determined using the agar dilution method (CLSI, EUCAST). MIC (Minimal inhibitor concentrations) values were determined against bacteria and fungus strains. Gram positive bacteria strains: Staphylococcus aureus ATCC 29213, S. aureus MRSA ATCC 43300 and Enterococcus faecalis ATCC 29212. Gram negative bacteria strains: Escherichia coli ATCC 25922, Pseudomonas aeruginosa ATCC 27853 and Acinetobacter baumannii ATCC 19606. Fungus strains: Candida albicans ATCC 10231, C. krusei ATCC 34135 ATCC 13803 and C. glabrata ATCC 90030. Precultured studies were done Mueller Hinton Broth medium (Bacteria) and RPMI 1640 Broth medium (Fungus). The standard inoculum yield of bacteria and fungi were prepared according to McFarland 0.5 equivalence. All tests were done at $800-12.5 \mu \mathrm{g} / \mathrm{mL}$ concentrations. Concentrations were made with distilled water. Reference drugs were used as fluconazole and amphotericin B (Fungus), amikacin, ampicillin and ciprofloxacin (Bacteria). Mueller Hinton Agar was dissolved by using water bath and sterilized by putting $9 \mathrm{~mL}$ in $15 \mathrm{~mL}$ sterile tubes. $1 \mathrm{~mL}$ of sample extracts were added to these tubes, mixed and poured into Petri dishes. Seven dilutions were prepared for each extract by this way. Standard inoculum 
of bacteria and fungi (106 CFUs/mL) were seeded on agar plates with a disposable inoculating loops $(0.01$ $\mathrm{mL})$.

All plates were evaluated at $35^{\circ} \mathrm{C}$ for $16-20$ hours for the bacterium and 48 hours for the fungi. The presence of colony formation was assessed growth, and the absence of colony was assessed as inhibition. Control plates were also used for each working series. The minimum concentration of dilution to prevent the growth of bacteria and fungi were determined as the minimal inhibitor concentration (MIC) [16-21].

\section{THE RESEARCH FINDINGS AND DISCUSSION}

\subsection{Phenolic Content}

The phenolic contents of $F$. platycarpa were determined using the HPLC method and the results and chromatograms were given in Table 1.

Table 1. Phenolic Contents of F. platycarpa

\begin{tabular}{|l|l|}
\hline & Phenolic Contents (ppm) \\
\hline Gallic acid & 14.63 \\
\hline Clorogenic acid & 19.71 \\
\hline Epicatechin & 20.22 \\
\hline Cinnamic acid & 33.105 \\
\hline Sringic acid & 0.39 \\
\hline Catechin & 84.92 \\
\hline Quercetin & 14.33 \\
\hline
\end{tabular}

As a result of HPLC screening seven phenolic compounds were identified in $F$. platycarpa. The highest concentration in detected phenolic compounds was Catechin with $84.92 \mathrm{ppm}$. The other compounds from the highest to the lowest concentrations were $20.22 \mathrm{ppm}$ epicatechin, $197.07 \mathrm{ppm}$ chlorogenic acid, 33.11 ppm cinnamic acid, $14.63 \mathrm{ppm}$ gallic acid, $14.33 \mathrm{ppm}$ quercetin and $0.39 \mathrm{ppm}$ syringic acid respectively. In previous studies, it has been reported that gallic acid has antimicrobial, anti-inflammatory, antidepressant, anti-parkinson, anti-diabetic, anti-malarial, diuretic, cardioprotective, anti-viral, antifungal, wound healing, anthelmintic and anxiolytic effects [22-30]. Chlorogenic acid has been reported to have anticancer, antioxidant, anti-inflammatory, cardiovascular, hepatoprotective, reno-protective, anti-diabetic and anti-lipidemic properties [31,32]. Epicatechin and catechin were determined to have antioxidant, antimicrobial, anti-inflammatory, anticancer effects [33-35]. Cinnamic acid has been reported as antiinflammatory, anti-oxidative, anti-tumor, anti-microbial, anti-hypertensive and anti-hyperlipidemic [36]. Syringic acid has been found to have antioxidant, antiproliferative, antiendotoxic, antimicrobial, antiinflammatory and anti-cancer effects [37]. Quercetin has been reported to have antioxidant, antiinflammation, antimicrobial and anti-apoptotic effects [38,39]. In this study, it was found that $F$. platycarpa contains high amounts of catechin, epicatechin chlorogenic acid. In this context, it has been determined that F. platycarpa may be a source for these phenolic compounds.

\subsection{TAS, TOS and OSI Results}

Oxidative stress can result in lipid peroxidation and oxidative DNA damage. It can also cause effects that can damage the cellular loop such as physiological adaptation mechanisms and imbalance of intracellular signal transduction [40,41]. Antioxidant compounds play an active role in reducing the effects of oxidative stress [42]. In this context, determination of the antioxidant capacities of plants is very important in terms of determination of new natural antioxidant sources. There are no studies in the literature that determine TAS, TOS and OSI values of $F$. platycarpa. According to our studies on $F$. platycarpa 6 different plant samples were taken and these samples were run in 5 replicates. When our studies, it is seen that the endogenous antioxidant compound capacity that the plant produces is $5.688 \pm 0.024 \mathrm{mmol} / \mathrm{L}$. The oxidant compound level of the plant, which was produced as a result of environmental effects and metabolic 
activities, was determined as $15.552 \pm 0.109 \mu \mathrm{mol} / \mathrm{L}$. It is determined that the oxidative stress level indicating how much the oxidant compounds were tolerated with the endogenous antioxidant compounds in percentage was $0.273 \pm 0.001$. According to the studies oxidative stress on plants, the TAS value of Mentha longifolia subsp. longifolia was reported as $3.628 \pm 0.234 \mathrm{mmol} / \mathrm{L}$, the TOS value was $4.046 \pm 0.615$ $\mu \mathrm{mol} / \mathrm{L}$ and the OSI value was $0.112 \pm 0.025$ [43]. In another study, the TAS value of Thermopsis turcica was reported as $2.06 \pm 0.09 \mu \mathrm{mol} / \mathrm{g}$ [44]. In another study, the TAS value of Brassica rapa was reported as $1.25 \mathrm{mmol} / \mathrm{L}$ [45]. The TAS, TOS and OSI values of $F$. platycarpa used in our study compared to these studies were found to be higher. In this context, it was determined that $F$. platycarpa has antioxidant potential and could be used as a natural antioxidant source. However, in terms of the TOS value, the higher levels indicate that the oxidant compounds in the plant are produced more by the environmental factors. Therefore, it was considered that the samples collected from more suitable regions for the oxidative stress condition of the plant could be used as an antioxidant source.

\subsection{Antimicrobial Activity Results}

In spite of the technological developments that have been experienced in recent years, the spread of infectious diseases cannot be controlled. Microorganisms are the leading cause of infectious diseases [46]. They are one of the oldest living things on the planet that existed on Earth for millions of years. Recently, the resistance of bacteria to synthetic antibiotics has become a global problem [47]. For this reason, researchers have considered the use of natural products such as medicinal plants for the production of new antibiotic drugs [48]. In this study EtOH, MeOH and DCM extracts of F. platycarpa were used and their activities on test microorganisms were determined. The results of the study were given in the Table 2 .

Table 2. Antimicrobial Activities of F. platycarpa

\begin{tabular}{|l|l|l|l|l|l|l|l|l|l|}
\hline & $\begin{array}{l}S . \\
\text { aureus }\end{array}$ & $\begin{array}{l}\text { S. } \\
\text { aureus } \\
\text { MRSA }\end{array}$ & $\begin{array}{l}\text { E. } \\
\text { faecalis }\end{array}$ & $\begin{array}{l}\text { E. } \\
\text { coli }\end{array}$ & $\begin{array}{l}\text { P. } \\
\text { aeruginosa }\end{array}$ & $\begin{array}{l}\text { A. } \\
\text { baumannii }\end{array}$ & $\begin{array}{l}\text { C. } \\
\text { albicans }\end{array}$ & $\begin{array}{l}\text { C. } \\
\text { glabrata }\end{array}$ & $\begin{array}{l}\text { C. } \\
\text { krusei }\end{array}$ \\
\hline EtOH & 800 & 800 & 800 & 800 & 400 & 400 & 800 & 400 & 400 \\
\hline MeOH & 200 & 200 & 200 & 400 & 200 & 200 & 400 & 200 & 200 \\
\hline DCM & 400 & 400 & 400 & 800 & 400 & 200 & 800 & 400 & 200 \\
\hline Ampicillin & 1.56 & 3.12 & 1.56 & 3.12 & 3.12 & - & - & - & - \\
\hline Amikacin & - & - & - & 1.56 & 3.12 & 3.12 & - & - & - \\
\hline Ciprofloksasin & 1.56 & 3.12 & 1.56 & 1.56 & 3.12 & 3.12 & - & - & - \\
\hline Flukanazol & - & - & - & - & - & - & 3.12 & 3.12 & - \\
\hline Amfoterisin B & - & - & - & - & - & - & 3.12 & 3.12 & 3.12 \\
\hline
\end{tabular}

200,400 and $800(\mu \mathrm{g} / \mathrm{mL})$ extract concentrations

According to Table 2 was examined, it was seen that the highest activity was determined as $\mathrm{MeOH}$ extract of the plant. When other extracts were compared, it was determined that DCM extract was higher than EtOH extract activity. In this study, the highest activity on S. aureus, S. aureus MRSA and E. faecalis were seen with at $200 \mu \mathrm{g} / \mathrm{mL}$ concentration of $\mathrm{MeOH}$ extract, then $400 \mu \mathrm{g} / \mathrm{mL}$ concentration of DCM extract and $800 \mu \mathrm{g} / \mathrm{mL}$ concentration of EtOH extract, respectively. Moreover, the highest activity on E. coli and C. albicans were seen at $400 \mu \mathrm{g} / \mathrm{mL}$ concentration of $\mathrm{MeOH}$ extract, then $800 \mu \mathrm{g} / \mathrm{mL}$ concentration of DCM and EtOH extracts. On the other hand, the highest activity on P. aeruginosa and C. glabrata were seen at $200 \mu \mathrm{g} / \mathrm{mL}$ concentration of $\mathrm{MeOH}$ extract, then $400 \mu \mathrm{g} / \mathrm{mL}$ concentration of DCM and EtOH extracts. Finally, the highest activity on A. baumannii and C. krusei were seen at $200 \mu \mathrm{g} / \mathrm{mL}$ concentration of $\mathrm{MeOH}$ and DCM extracts, then $400 \mu \mathrm{g} / \mathrm{mL}$ concentration of EtOH extract. Previous studies have reported that methanol, chloroform, ethyl acetate and hexane extracts of $F$. platycarpa are effective at different concentrations on Staphylococcus aureus, Enterococcus faecalis and Candida albicans [49]. In comparison to this study, it was determined that $\mathrm{EtOH}, \mathrm{MeOH}$ and DCM extracts of $F$. platycarpa were effective against E. coli, P. aeruginosa, A. baumannii, C. glabrata and C. krusei at $200-800 \mu \mathrm{g} / \mathrm{mL}$ concentrations. In this context, it was determined that $F$. platycarpa can be used as a natural antimicrobial source for the tested microorganisms. 


\section{CONCLUSION}

In this study, phenolic contents, antioxidant and antimicrobial activities of endemic $F$. platycarpa plant, collected from Gaziantep (Turkey) were determined. As a result of the studies, it was determined that the plant contains gallic acid, chlorogenic acid, epicatechin, cinnamic acid, syringic acid, catechin and quercetin. It was also determined that the plant could be a rich natural source for these identified compounds. On the other hand, it is observed that the plant has antioxidant potential. As a result, biological activity of the plant was determined for the first time and it could be used as a pharmacological agent.

\section{CONFLICTS OF INTEREST}

No conflict of interest was declared by the authors.

\section{REFERENCES}

[1] Mohammed, F.S., Karakaş, M., Akgül, H., Sevindik, M., "Medicinal Properties of Allium calocephalum Collected from Gara Mountain (Iraq)", Fresen. Environ. Bull., 28(10): 7419-7426, (2019).

[2] Saxena, M., Saxena, J., Nema, R., Singh, D., Gupta, A., "Phytochemistry of medicinal plants", J. Pharmacogn. Phytochem., 1: 168-182, (2013).

[3] Mohammed, F. S., Akgul, H., Sevindik, M., Khaled, B. M. T., "Phenolic content and biological activities of Rhus coriaria var. zebaria", Fresen. Environ. Bull., 27(8), 5694-5702, (2018).

[4] Ji, H.F., Li, X.J., Zhang, H.Y., "Natural products and drug discovery: can thousands of years of ancient medical knowledge lead us to new and powerful drug combinations in the fight against cancer and dementia?", EMBO Reports, 10:194-200, (2009).

[5] Ekor, M., "The growing use of herbal medicines: issues relating to adverse reactions and challenges in monitoring safety", Front. Pharmacol, 4: 177, (2014).

[6] Pan, S.Y., Zhou, S.F., Gao, S.H., Yu, Z.L., Zhang, S.F., Tang, M.K., Sun, J.N., Ma, D.L., Han, Y.F., Fong, W.F., Ko, K.M., "New perspectives on how to discover drugs from herbal medicines: CAM's outstanding contribution to modern therapeutics", Evid.-Based Complement. Altern. Med., (2013). http://dx.doi.org/10.1155/2013/627375

[7] Ghasemi Pirbalouti, A., Izadi, A., Malek Poor, F., Hamedi, B., "Chemical composition, antioxidant and antibacterial activities of essential oils from Ferulago angulata", Pharm. Biol., 54: 2515-2520, (2016).

[8] Bakar, F., Karakay, S., Delimustafaoğlu, B., Gül, F., Sibel, K.C., “Anticancer effect of Ferulago mughlea Peşmen (Apiaceae) on cancer cell proliferation”, Iran J. Pharm. Res., 15: 501, (2016).

[9] Harborne, J.B., "The Natural Coumarins: Occurrence, Chemistry and Biochemistry (Book) ”, Plant, Cell \& Environ., 5: 435-436, (1982). 
[10] Shahbazi, Y., Shavisi, N., Karami, N., Shabnam, K., "Chemical Composition and in Vitro Antibacterial Activity of Ferulago angulata (Schlecht.) Boiss Essential Oil”, Pharm. Sci., 21: 6-11, (2015).

[11] El-Thaher, T.S., Matalka, K.Z., Taha, H.A., Badwan, A.A., "Ferula harmonis 'zallouh'and enhancing erectile function in rats: efficacy and toxicity study”, Int. J. Impot. Res., 13: 247, (2001).

[12] Ameen, B. A. H., "Phytochemical study and cytotoxic activity of Ferulago angulata (Schlecht) Boiss, from Kurdistan-region of Iraq", IJIRAE., 2014;1: 1-5, (2014).

[13] Caponio, F., Alloggio, V., Gomes, T., "Phenolic Compounds of Virgin Olive Oil: Influence of Paste Preparation Techniques”, Food Chem., 64: 203-209, (1999).

[14] Erel, O., "A novel automated direct measurement method for total antioxidant capacity using a new generation, more stable ABTS radical cation", Clin. Biochem., 37: 277-285, (2004).

[15] Erel, O., "A new automated colorimetric method for measuring total oxidant status", Clin. Biochem., 38: 1103-1111, (2005).

[16] Bauer, A.W., Kirby, W.M., Sherris, J.C., Turck, M., "Antibiotic susceptibility testing by a standardized single disk method”, Am. J. Clin. Pathol., 45: 493-496, (1966).

[17] CLSI (The Clinical and Laboratory Standards Institute). "Antimicrobial Susceptibility Testing of Anaerobic Bacteria; Approved Standard—Eighth Edition (M11-A8)", (2012).

[18] EUCAST (European Committee on Antimicrobial Susceptibility Testing). "Breakpoint tables Fungal isolate for interpretation of MICs", Version 7.0. (2014).

[19] EUCAST (European Committee on Antimicrobial Susceptibility Testing). "Breakpoint tables for Bacteria interpretation of MICs and zone diameters", Version 5.0 (2015).

[20] Hindler, J., Hochstein, L., Howell, A., "Preparation of routine media and reagents used in antimicrobial susceptibility testing", Part 1. McFarland standards, p. 5.19.1-5.19.6. In H. D. Isenberg (ed) Clinical microbiology procedures handbook, vol. 1. American Society for Microbiology, Washington, D.C. (1992).

[21] Matuschek, E., Brown, D.F., Kahlmeter, G., "Development of the EUCAST disk diffusion antimicrobial susceptibility testing method and its implementation in routine microbiology laboratories”, Clin. Microbiol. Infect., 20: 255-266, (2014).

[22] Kroes, B.H., van den Berg, A.J., van Ufford, H.C.Q., van Dijk, H., Labadie, R.P., "Antiinflammatory activity of gallic acid", Planta. Med., 58: 499-504, (1992).

[23] Griffith, R., Chanphen, R., Leach, S.P., Keller, P.A., "New anti-malarial compounds from database searching”, Bioorg. Med. Chem. Lett., 12: 539-542, (2002). 
[24] Prasad, C.N., Anjana, T., Banerji, A., Gopalakrishnapillai, A., "Gallic acid induces GLUT4 translocation and glucose uptake activity in 3T3-L1 cells”, FEBS Lett., 584:531-536, (2010).

[25] Guan, H.H., Ming, H.H., Chuan, S.C., Shyh, S.H., Pei, H.S.H., Ming, T.Y., Bor, S.W., "Analgesic and Anti-Inflammatory Activities of Aqueous Extracts of Fructus Ligustri Lucidi”, J. Food Drug Anal., 20: 617-627, (2012).

[26] Angelica, G.C., Candida, A.L., Kassuya, I.I., Joao, B.C., Petrovick, P.R., “Antiinflammatory, antiallodynic effects and quantitative analysis of gallic acid in spray dried powders from Phyllanthus niruri leaves, stems, roots and whole plant”, Rev. Bras. Farmacognosia, 23: 124-31, (2013).

[27] Borges, A., Ferreira, C., Saavedra, M.J., SimÃ $\mu$ es, M., "Antibacterial activity and mode of action of ferulic and gallic acids against pathogenic bacteria”, Microb. Drug. Resist., 19: 256-265, (2013).

[28] Chhillar, R., Dhingra, D., "Antidepressant-like activity of gallic acid in mice subjected to unpredictable chronic mild stress”, Fundam. Clin. Pharmacol., 27: 409-418, (2013).

[29] Roberto, D.G., Remigio, L.S., Elias, O.S., Hector, T.A., "Comparative antibacterial effect of gallic acid and catechin against Helicobacter pylori”, LWT - Food Sci. Tec., 54: 331-335, (2013).

[30] Nayeem, N., Asdaq, S.M.B., Salem, H., Ahel-Alfqy, S., "Gallic Acid: A Promising Lead Molecule for Drug Development", J. App. Pharm., 8: 213, (2016).

[31] Zhao, M., Wang, H., Yang, B., Tao, H., "Identification of cyclodextrin inclusion complex of chlorogenic acid and its antimicrobial activity", Food Chem., 120: 1138-1142, (2010).

[32] Maalik, A., Bukhari, S.M., Zaidi, A.S.M.A., Shah, K.H., Khan, F.A., "Chlorogenic acid: a pharmacologically potent molecule", Acta. Pol. Pharm., 73: 851-854, (2016).

[33] Pushp, P., Sharma, N., Joseph., G.S., Singh, R.P., "Antioxidant activity and detection of (-) epicatechin in the methanolic extract of stem of Tinospora cordifolia", J. Food Sci. Tec., 50: 567572, (2013).

[34] Duangyod, T., Palanuvej, C., Ruangrungsi, N., "Pharmacognostic evaluation with reference to catechin content and antioxidant activities of pale catechu in Thailand", J. Adv. Pharm. Technol. Res., 6: 97, (2015).

[35] Shay, J., Elbaz, H.A., Lee, I., Zielske, S.P., Malek, M.H., Hüttemann M “Molecular mechanisms and therapeutic effects of (-)-epicatechin and other polyphenols in cancer, inflammation, diabetes, and neurodegeneration", Oxidative Med. Cell. Longevity, (2015). http://dx.doi.org/10.1155/2015/181260

[36] Peperidou, A., Pontiki, E., Hadjipavlou-Litina, D., Voulgari, E., Avgoustakis, K., "Multifunctional cinnamic acid derivatives", Molecules, 22: 1247, (2017).

[37] Cikman, O., Soylemez, O., Ozkan, O.F., Kiraz, H.A., Sayar, I., Ademoglu, S., Taysi, S., Karaayvaz, M., "Antioxidant Activity of Syringic Acid Prevents Oxidative Stress in L-arginine-Induced Acute Pancreatitis: An Experimental Study on Rats”, Int. Surg., 100: 891-896, (2015). 
[38] Cushnie, T.T., Lamb, A.J., “Antimicrobial activity of flavonoids”, Int. J. Antimicrob. Agents, 26: 343-356, (2005).

[39] Alrawaiq, N.S., Abdullah, A., "A review of flavonoid quercetin: metabolism, bioactivity and antioxidant properties”, Int. J. Pharm. Tech. Res., 6: 933-941, (2014).

[40] Mello, T., Zanieri, F., Ceni, E., Galli, A., "Oxidative stress in the healthy and wounded hepatocyte: a cellular organelles perspective", Oxidative Med. Cell. Longevity, (2016). http://dx.doi.org/10.1155/2016/8327410

[41] Sevindik, M., "The novel biological tests on various extracts of Cerioporus varius", Fresen. Environ. Bull., 28(5):3713-3717, (2019).

[42] Sevindik, M., Akgul, H., Bal, C., Selamoglu, Z., "Phenolic contents, oxidant/antioxidant potential and heavy metal levels in Cyclocybe cylindracea", Indian Journal of Pharmaceutical Education and Research, 52(3):437-441, (2018).

[43] Sevindik, M., Akgul, H., Pehlivan, M., Selamoglu, Z., "Determination of Therapeutic Potential of Mentha longifolia ssp. longifolia”, Fresen. Environ. Bull., 26: 4757-4563, (2017).

[44] Aksoy, L., Kolay, E., Ağı̈önü, Y., Aslan, Z., Kargığlu, M., "Free radical scavenging activity, total phenolic content, total antioxidant status, and total oxidant status of endemic Thermopsis turcica", Saudi J. Biol. Sci., 20: 235-239, (2013).

[45] Gul, S., Ahmed, S., Gul, H., Shad, K.F., Zia-Ul-Haq, M., Badiu, D., "The antioxidant potential of Brassica rapa L. on glutathione peroxidase, superoxide dismutase enzymes and total antioxidant status", RJLabM, 21:161-169, (2013).

[46] Sevindik, M., "Investigation of antioxidant/oxidant status and antimicrobial activities of Lentinus tigrinus", Advances in Pharmacological Sciences, 2018:1-4, (2018).

[47] Sevindik, M., Akgul, H., Selamoglu, Z., Braidy, N., "Antioxidant and Antigenotoxic Potential of Infundibulicybe geotropa Mushroom Collected from Northwestern Turkey", Oxidative Medicine and Cellular Longevity, 2020:1-8, (2020).

[48] Abdallah, E.M., "Plants: An alternative source for antimicrobials", J. Appl. Pharm. Sci., 1: 16-20, (2011).

[49] Satır, E., "Ferulago platycarpa Boiss. \& Hon. Research on Pharmaceutical Botany", Ankara University Institute of Health Sciences. Master Thesis. Ankara (Turkey), (2006). 